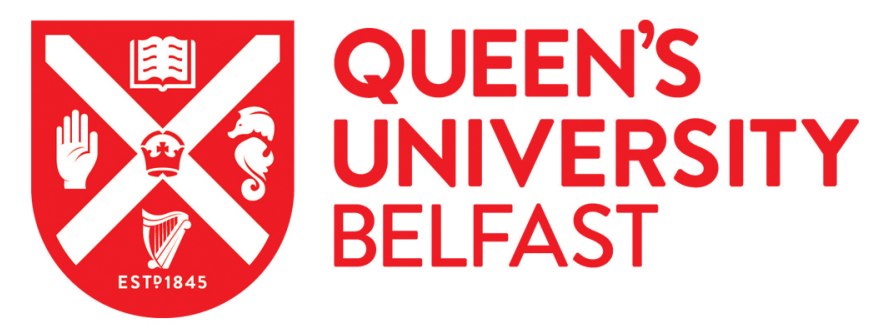

\title{
Extensive DNA inversions in the B. fragilis genome control variable gene expression
}

Cerdeno-Tarraga, A. M., Patrick, S., Crossman, L. C., Blakely, G., Abratt, V., Lennard, N., Poxton, I., Duerden, B., Harris, B., Quail, M. A., Barron, A., Clark, L., Corton, C., Doggett, J., Holden, M. T., Larke, N., Line, A., Lord, A., Norbertczak, H., ... Parkhill, J. (2005). Extensive DNA inversions in the B. fragilis genome control variable gene expression. Science, 307(5714)(5714), 1463-1465. https://doi.org/10.1126/science.1107008

\section{Published in:}

Science

Queen's University Belfast - Research Portal:

Link to publication record in Queen's University Belfast Research Portal

\section{General rights}

Copyright for the publications made accessible via the Queen's University Belfast Research Portal is retained by the author(s) and / or other copyright owners and it is a condition of accessing these publications that users recognise and abide by the legal requirements associated with these rights.

Take down policy

The Research Portal is Queen's institutional repository that provides access to Queen's research output. Every effort has been made to ensure that content in the Research Portal does not infringe any person's rights, or applicable UK laws. If you discover content in the Research Portal that you believe breaches copyright or violates any law, please contact openaccess@qub.ac.uk. 


\section{Supporting Online Material}

\section{Materials and Methods}

This sequence strain NCTC 9343 was originally isolated from an abdominal infection at St Bartholomew’s Hospital, London in 1955. The culture from which DNA was produced for the genomic sequencing was enriched for the EDL phase, with minimum subculture from an early freeze dried stock culture, but remained antigenically mixed. Bacteria were grown in defined medium broth (1) in an anaerobic cabinet (MACS Anaerobic Workstation Don Whitley Scientific, Shipley, UK; $80 \%$ N2, 10\% CO2 and 10\% H2). Percoll density gradient enrichment was used to obtain populations that were non-capsulate by light microscopy as described previously (2).

DNA was isolated using a modification of the basic protocol for preparation of genomic DNA from bacteria detailed in Ausubel et al. (3). In brief, bacterial cells were lysed in $10 \mathrm{mM}$ TrisHCl 1mM EDTA buffer (pH 8.0) containing SDS (0.5\%), lysozyme $(4 \mathrm{mg} / \mathrm{ml})$ and proteinase $\mathrm{K}(0.1 \mathrm{mg} / \mathrm{ml})$. Polysaccharide was precipitated using cetyltrimethylammonium bromide (CTAB) and DNA extracted with chloroform: isoamyl alcohol and phenol:choloroform:isoamyl alcohol mixtures. DNA was precipitated using isopropanol, spooled out with a glass rod and washed in ethanol. The initial genome assembly was obtained from 94,563 paired end sequences (giving 10-fold coverage) derived from four pUC18 genomic shotgun libraries (with insert sizes ranging from 2.0 to $4.0 \mathrm{~kb}$ ) using big-dye terminator chemistry on ABI3700 automated sequencers. This was supplemented with 4,991 end-reads from an m13mp18 library with an insert size of 2.0-4.0 kb; 3,388 paired-end sequences 
from a pBACe3.6 library with insert sizes of 10-18 kb (a clone coverage of 4.56-fold) were used as a scaffold. All identified repeats were bridged by read-pairs or endsequenced PCR products. A further 4,594 sequencing reads were generated during finishing. The sequences were assembled, finished and annotated as described previously (4), using Artemis (5) to collate data and facilitate annotation. The DNA and encoded protein sequences of related species were compared using the Artemis Comparison Tool (ACT) (K. Rutherford, unpublished; http://www.sanger.ac.uk/Software/ACT/). Orthologous gene sets were calculated by reciprocal best match FASTA comparisons, with subsequent manual curation. Pseudogenes had one or more mutations that would ablate expression; each of the inactivating mutations was subsequently checked against the original sequencing data.

\section{Genomic comparison of Bacteroides fragilis with Bacteroides}

\section{thetaiotaomicron}

The recently sequenced B. thetaiotaomicron strain VPI-5482 (ATCC 29148)(6), has a larger genome of $6.26 \mathrm{Mb}$ containing 4779 predicted genes and an unusually low ratio of gene number to genome size with 0.763 genes/kb (6). The proportion of the genome devoted to protein coding (89.3\%) is, however, not unusual. This is explained by a high average gene length (1173 bp), and abundant large proteins of over 600 aa. At 1087bp the average gene length in $B$. fragilis is slightly shorter, but it is still amongst the highest so far reported in bacteria.

Despite their con-generic taxonomic status, B. fragilis and B. thetaiotaomicron share remarkably few orthologous genes (as measured by reciprocal-best-match FASTA analysis). Only 2,384 predicted genes are shared, with $B$. fragilis containing 
1890 unique genes (44.3\% of its coding capacity), and B. thetaiotaomicron containing 2337 (48.9 \%). This is considerably greater than the number of genes unique to Salmonella vs. Escherichia (7), or to Escherichia vs. Yersinia (8) indicating the breadth of diversity amongst Bacteroides. This is underlined by the average amino-acid identity between orthologous gene pairs; just 76.6\%.

A comparison of $B$. thetaiotaomicron with $B$. fragilis was carried out to determine the nature of the non-orthologous genes. A particularly interesting feature is the extent of diversity of cell envelope, transmembrane, polysaccharide and outer membrane proteins compared to B. thetaiotaomicron (Fig. S2); B. fragilis unique surface proteins include 128 inner membrane proteins, 2 peptidoglycan associated proteins and 57 predicted outer membrane proteins. In addition, there are 102 unique surface polysaccharide biosynthesis genes, arranged in 10 gene clusters (seven of which are controlled by invertible promoters). This variation in surface polysaccharides and other antigens may be significant in relation to the difference in the pathogenic potential between $B$. fragilis and B. thetaiotaomicron. In terms of transcriptional regulators, the most abundant class is the AraC family of transcriptional regulators, with 20 being unique compared to B. thetaiotaomicron. An additional point of interest in the $B$. thetaiotaomicron genome is the significantly increased number of sigma factors and anti-sigma factors relative to genome size; of a total of 45 sigma factors in $B$. fragilis there are 16 that are not conserved in $B$. thetaiotaomicron. 


\section{Additional DNA inversions}

In addition to the restriction/modification intergenic shufflon, a further three different systems were identified. The simplest involves BF0335 and BF0336 (IR-P), which encode two parts of a sensor-regulator system. BF0336 encodes the putative sensor domain and transmembrane domain, and BF0335 encodes the histidine kinase, response receiver and DNA binding domains. The first CDS is flanked by inverted repeats su such that recombination will fuse the two into a single coding sequence. Other fused sensor-regulator genes, lacking invertible regions are present both in $B$. fragilis and B. thetaiotaomicron (6).

A further two more complex systems involve gene pairs similar to ragA (susC like) and ragB of $P$. gingivalis (Fig. 1). In $P$. gingivalis RagB is a major immunodominant surface antigen and $\operatorname{ragA} B$ positive strains are associated with sites of periodontal destruction (9) SusC is an outer membrane protein, which in association with SusD, binds starch at the bacterial surface in B. thetaiotaomicron (10). In one system, five ragA/B like gene pairs (BF1716/8, BF1719/20, BF1722/21, BF1798/7 and BF1803/2; IR-EE), at either end of a 90 kb region of the chromosome, have an extensive repeat sequence (over 200bp) that overlaps the start codon of the ragA homologs (Fig. 1C). One of these (BF1803) is downstream of an invertible promoter (Table S2A, Group 2; IR-T), and recombination between these larger repeats could bring any one of the alternative gene pairs downstream of this promoter by inversion of the intervening sequence. Evidence that this was indeed occurring was found in the shotgun data. A potential recombinase (BF1795) is located close to BF1797/9 and is associated with the putative conjugative transposon encoded within the $90 \mathrm{~kb}$ central region. 
A second independent system involves a further group of four co-located $\mathrm{rag} A / B$ like gene pairs (BF0590, BF0592, BF0594 and BF0596; Table 1b, IR-CC), where three of the susC (ragA-like) homologues lack an appropriate start codon. Within the 5' end of the coding region of these genes is a 60bp inverted repeat, identical to that found 68 amino-acids downstream of the start codon of the fourth, BF0594 (Fig. 1C). Recombination between these inverted repeats would fuse the coding sequences of any of these genes to the promoter and translation initiation signals of BF0594. Again, evidence was seen that this was occurring in the shotgun. Another potential recombinase (BF0593) is encoded adjacent to these genes. Examples of similar multiple intergenic inversions include omp1 of Dichelobacter (formerly Bacteroides) nodosus and the variable surface antigens of Mycoplasma pulmonis (11). There are also invertible promoter regions upstream of nine other susC homologues (Table S2A) and several other predicted outer membrane proteins belonging to a related family (Table S4). This indicates that there is a strong selective pressure in favour of the variation of these molecules, which suggests that they play an important role in the survival of $B$. fragilis.

Several invertible promoters are between divergent coding regions, thus potentially driving variable transcription of other genes. These include a sialoconjugate degradation operon (IR-T; BF1804-BF1817); a sigma factor (IR-W; BF2944), indicating the possibility of cascade regulation; and the cpn10-cpn60 operon encoding the major chaperones GroES and GroEL (IR-M). These genes are known to be essential, and have not been seen to be phase-variable, in other organisms. Analysis of the promoter region for cpn10 in B. thetaiotaomicron shows that it is 
flanked by 29bp inverted repeats whose sequence is similar to that of $B$. fragilis, although it has not been identified as being invertible.

An 11kb region of the plasmid (pBF9343) containing partition, replication and mobilisation functions, and the invertase finB, undergoes inversion (Fig. S1B). There appears to be no clear functional consequence of this, although it may affect the transcription of $f i n B$, as one of the ends of the inversion is $~ 100$ bp upstream of its start site. As both FinB and the chromosomally-encoded FinA (MpiA) may be involved in inversion of hin-like invertible promoters, this raises the possibility of a random variation in the rate of variation at those promoters in plasmid-containing strains.

\section{Virulence associated genes}

Iron is essential for the growth of most bacteria. Within the human host iron is sequestered such that the free iron concentration is estimated to be $10^{-18} \mathrm{M}$, well below the concentration necessary to support bacterial growth. To overcome this iron famine, pathogenic bacteria have evolved specific adaptive mechanisms for obtaining iron. One is the production of secreted iron chelating compounds termed siderophores that sequester iron and are subsequently re-imported through membrane receptors (12). Internalisation is generally performed by TonB-dependent outer-membrane receptors, of which $B$. fragilis contains at least 57 , and is energised by the TonB/ExbBD complex (BF3737, BF3738 and BF3739). An FhuA (Vibrio cholerae ferrichrome receptor) homologue, together with a two-component sensor-regulator pair and a complete sigma, anti-sigma and anti-anti-sigma factor system (BF2844, BF2842 and BF2843) is evident. Whether $B$. fragilis synthesises siderophores or 
utilizes those produced by other bacteria remains to be determined, although a nonribosomal peptide synthase (BF2837), an enzyme family known to be involved in the biosynthesis pathway for other siderophores, is located nearby and may be part of a siderophore biosynthesis system. In addition, there are two periplasmic bindingprotein dependent iron uptake systems, of the ferric citrate FecCD family (BF1185 and BF2247), each with an associated periplasmic iron-binding protein. The putative siderophore uptake systems appear to be independent of the already identified ironrepressible haem uptake protein HupA that forms part of a haem binding outer membrane protein complex (13). Although growth is severely limited in the absence of haem (14), B. fragilis does not produce zones of haemolysis on blood agar. There are, however, 13 CDSs, fewer than in the $B$. thetaiotaomicron genome, which may encode a haemolytic function. One of these (BF0270) is similar to the haemolysin A of Prevotella melaninogenica (formerly Bacteroides melaninogenicus). Interestingly, within the associated CDSs (BF0266-0269) there is a putative haem receptor, suggesting that this might be a haem acquisition operon.

Extracellular enzymes, potentially capable of degrading components of the host's extracellular matrix, host cells and tissue, and therefore potentially involved in B. fragilis virulence, include hyaluronidase, chondroitin sulphatase, fibrinolysin, DNAase, lipases, proteases and neuraminidases (15). Bacterial sialidases or neuraminidases that remove the sialic acid residues from host oligosaccharides are implicated in bacterial virulence as they potentially interfere with normal host cell function. The neuraminidase NanH (BF1806) has previously been sequenced from $B$. fragilis and a second, highly similar, gene is present (BF4051), which could be equivalent to the second previously reported in B. fragilis strain SBT3182 by Tanaka, 
et al. (16) The observed degradation of hyaluronic acid, a component of the host's extracellular matrix, may be due to BF3796, which is similar to the hyaluronidase encoded by a Streptococcus pyogenes bacteriophage (17). Three putative tricorn-like proteases (BF0080, 2517 and 3752) with similarity in the beta-propeller, PDZ and catalytic domains are evident, but as in the MdsD protein of Prevotella sp, they also contain a putative signal peptide (18). Which of the potentially secreted putative 23 peptidases and 2 lipases are involved in virulence rather than nutrition remains to be determined.

Attachment to host tissues is key to the virulence of many pathogenic bacteria, and can be promoted by a variety of adhesins. The non-capsulate/EDL population of B. fragilis haemagglutinates erythrocytes (19). One haemagglutinin (BF1428) that has a homologue in $B$. thetaiotaomicron is evident; however, no fimbrial genes have been identified, despite reports of their observation in other strains (20). There is no evidence for type III, IV, autotransporter or two-partner secretion systems nor flagellar biosynthesis systems in the $B$. fragilis genome, hence secreted virulence determinants are likely to be exported via Hly-type I secretion systems such as BF0010 and BF0011, BF0608 and BF0610 or BF3811 and BF3812, which are similar to the haemolysin type I secretion system HlyDB from E. coli (21), or via the type II general secretion pathway. B. fragilis produces copious quantities of enzymecontaining outer membrane vesicles (22). This may therefore be an important export mechanism. 


\section{DNA recombination and repair of metronidazole induced DNA damage}

The current drug of choice in treating $B$. fragilis infections, metronidazole, is activated intracellularly via anaerobic reduction of the nitro group and interacts with DNA causing strand breaks. RecA-mediated strand exchange is required for repair of DNA breaks, the importance of which is shown by the sensitivity of a $B$.

thetaiotaomicron recA mutant to metronidazole and other DNA damaging agents (23). RecA (BF1180) is 60\% identical to E. coli RecA and can complement an E. coli recA mutant, demonstrating that DNA repair pathways are conserved in B. fragilis(24).

Two major pathways of recombination have been extensively studied in the model organisms E. coli and Bacillus subtilis; single-strand gap repair mediated by the RecFOR proteins and double-strand break repair (reviewed in ref. 25) Specific DExx motif helicases, belonging to Superfamily I, are essential in cells expressing RecF; these are Rep and UvrD in Gram negative bacteria and PcrA in Gram positive bacteria (26). B. fragilis contains a total of 24 putative DNA helicases, compared to 11 in E. coli, the functional significance of which is unknown. RecFOR homologues are present in $B$. fragilis together with two homologues of the PcrA helicase usually found in Gram positive bacteria. The presence of single PcrA homologues has been suggested to be a hallmark of Gram positive bacteria (26). It remains to be determined whether the two homologues in B. fragilis have separate roles or overlapping functions analogous to the activities of Rep and UvrD in E. coli.

Double-strand break repair is mediated by RecBCD in E. coli and AddAB in $B$. subtilis (25). B. fragilis contains a CDS (BF0679) encoding a homologue of RecD but does not contain identifiable homologues of RecBC or AddAB. The RexAB ATPdependent exonuclease/helicase has been implicated in repair of double-strand breaks 
in the Gram positive bacterium Lactobacillus lactis (27). There is a single RexA (BF2192) homologue in B. fragilis but no identifiable RexB. A potential hypothesis is that double-strand break repair in B. fragilis is mediated by a novel mechanism where the joint action of the RexA and RecD helicases unwind the DNA duplex with concurrent degradation by the exonuclease function of RexA until the equivalent of a chi site is encountered. This combination of helicases of opposite polarities (RecD has 5'-3' while RexA has 3'-5' activity) would be analogous to the helicase functions present in the RecBCD complex (28).

The sequence and annotation of the genome are available with further details from http://www.sanger.ac.uk/Projects/B_fragilis/. 


\section{Supporting Figures:}

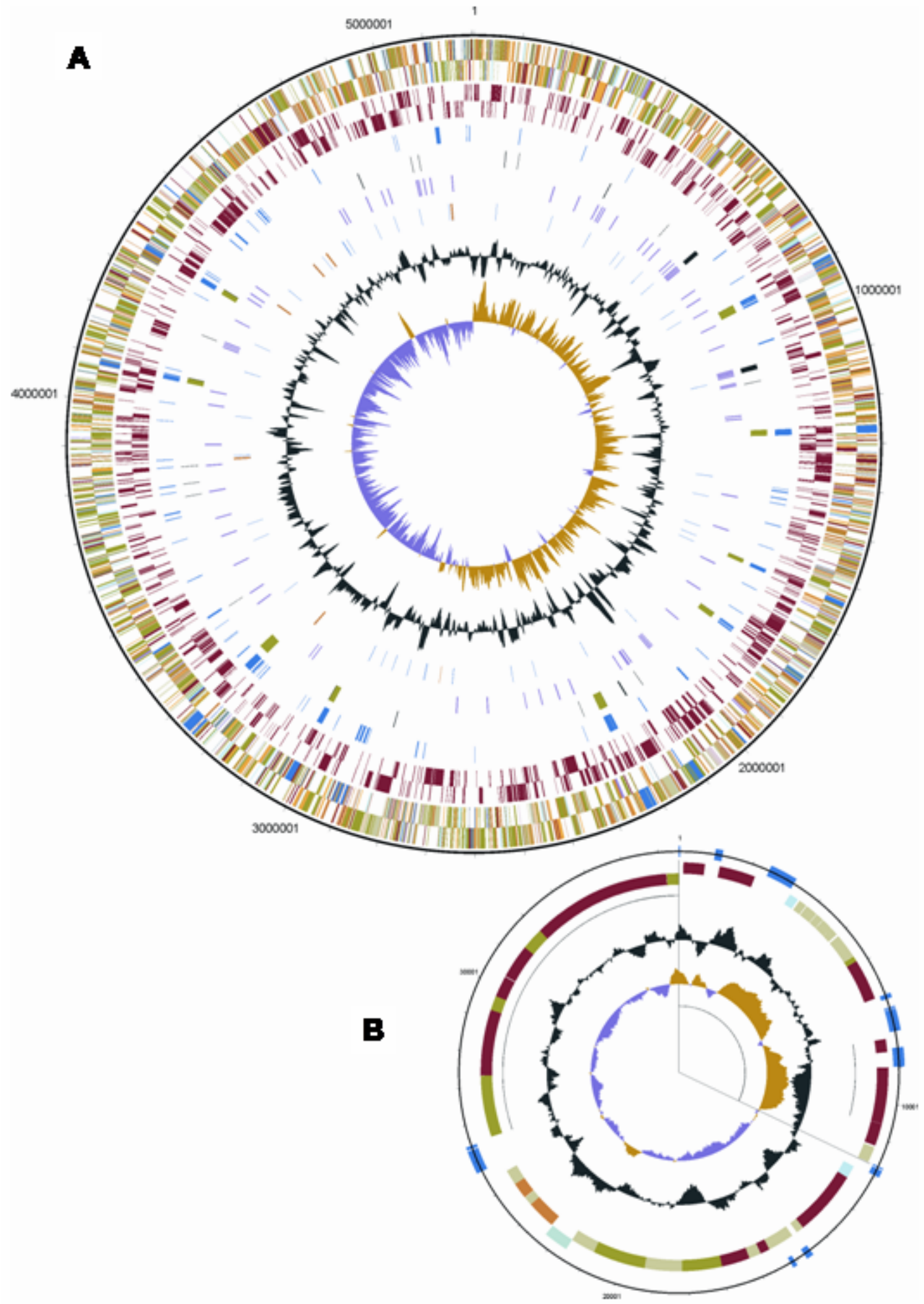

Figure S1: A) Circular representation of the $B$. fragilis NCTC9343 chromosome: From the outer to the inner circle: Circle 1: DNA coordinates (origin in base 1); Circles 2+3: all CDSs 
(forward and reverse strands); Circles 4+5: Unique CDSs in B. fragilis as compared with $B$. thetaiotaomicron CDSs (forward and reverse strands); Circle 6: Pathogenicity related CDSs (blue); Circle 7: polysaccharide biosynthesis clusters (green) and invertible regions (black); Circle 8: SusC homologues (pink); Circle 9: rRNAs (orange) and tRNAs (blue); Circle 10: $\mathrm{G}+\mathrm{C}$ content (plotted using a 10Kb window); Circle 11: GC skew $((\mathrm{G}-\mathrm{C}) /(\mathrm{G}+\mathrm{C})$ ) (plotted using a $10 \mathrm{~Kb}$ window). Colour coding for circles 2 and 3: dark blue;

pathogenicity/adaptation, black; energy metabolism, red; information transfer, dark green; surface associated, cyan; degradation of large molecules, magenta; degradation of small molecules, yellow; central/intermediary metabolism, pale green; unknown, pale blue; regulators, orange; conserved hypothetical, brown; pseudogenes, pink; phage+IS elements, grey; miscellaneous. B) Circular representation of the pBF9343 plasmid: From the outer to the inner circle: Circle 1: DNA coordinates with repeats marked as blue boxes; Circles 2+3: CDSs (forward and reverse strands); Circle 4: Transfer region marked with black line; Circle 5: Mobilisation region marked with black line; Circle 6: $\mathrm{G}+\mathrm{C}$ content (plotted using a $1 \mathrm{~Kb}$ window); Circle 7: GC skew ((G-C)/(G+C)) (plotted using a $1 \mathrm{~Kb}$ window); Circle 8: Inverted region marked with black line.

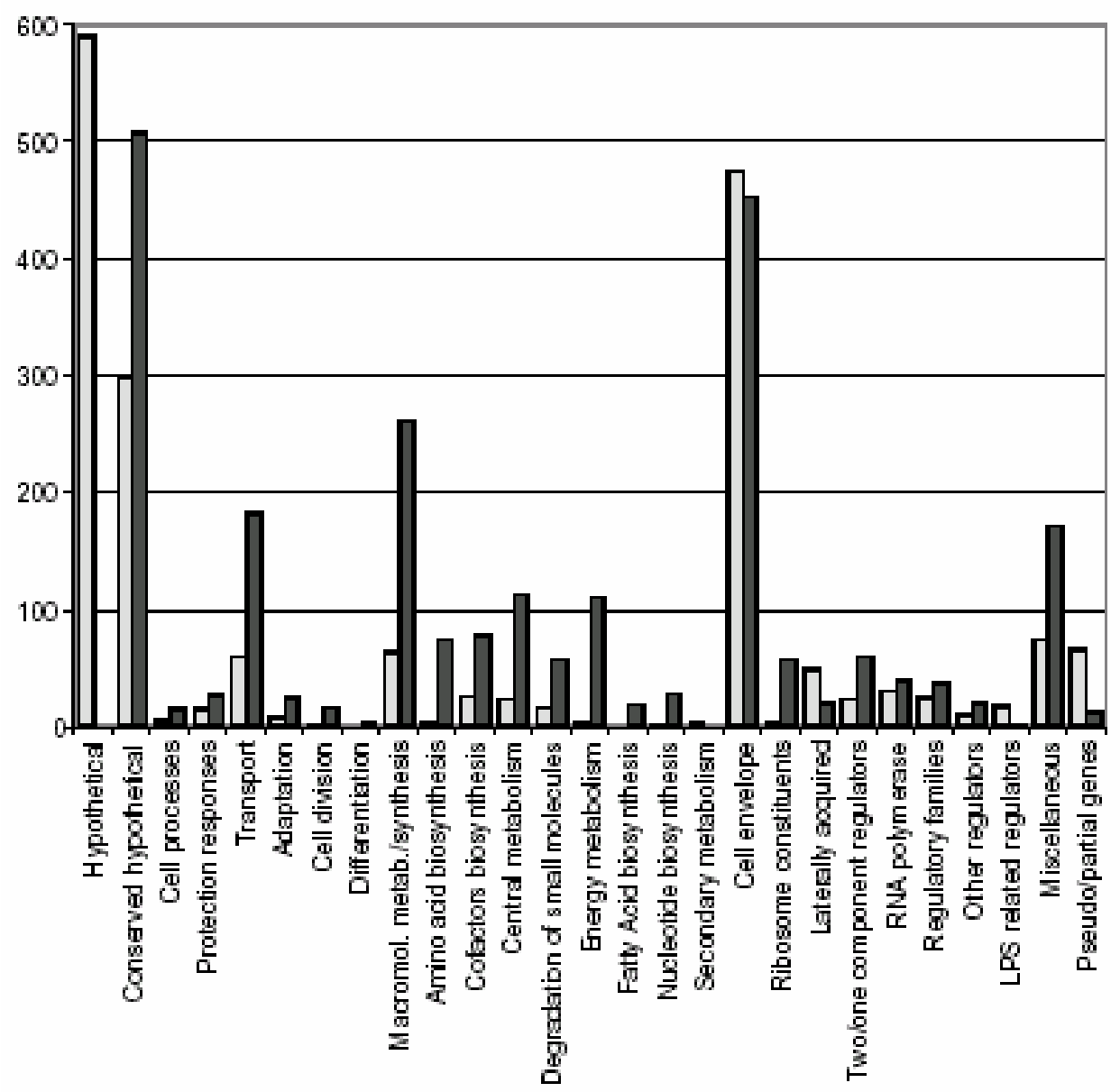

Figure S2: Numbers of orthologous genes between B. fragilis and B. thetaiotaomicron (dark grey), and genes unique to $B$. fragilis (light grey) within specific functional categories. 
Supporting Tables:

Table S1 - General features of the B. fragilis genome.

\begin{tabular}{|l|l|l|}
\hline Chromosome & Size (bp) & $5,205,140$ \\
\cline { 2 - 3 } & G+C content (\%) & 43.19 \\
\cline { 2 - 3 } & CDSs & 4,274 \\
\cline { 2 - 3 } & of which pseudogenes & 70 \\
\cline { 2 - 3 } & Coding density (\%) & 88.1 \\
\cline { 2 - 3 } & Average gene length (bp) & 1,091 \\
\cline { 2 - 3 } & Ribosomal RNAs & 19 \\
\cline { 2 - 3 } & Transfer RNAs & 73 \\
\cline { 2 - 3 } & IS/transposon elements & 24 \\
\hline \multirow{5}{*}{ Plasmid pBF9343 } & Size (bp) & 36,560 \\
\cline { 2 - 3 } & G+C content (\%) & 32.24 \\
\cline { 2 - 3 } & CDSs & 48 \\
\cline { 2 - 3 } & Coding density (\%) & 85.0 \\
\cline { 2 - 3 } & Average gene length (bp) & 652 \\
\hline
\end{tabular}

Table S2A - Invertible promoters.

\begin{tabular}{|c|c|c|c|c|c|}
\hline Group & $\begin{array}{l}\text { Average } \\
\text { length of } \\
\text { fin regions } \\
\text { (bp) }\end{array}$ & $\begin{array}{l}\text { Invertible } \\
\text { region } \\
\text { (IR) }\end{array}$ & Coordinates & $\begin{array}{l}\text { Active in } \\
\text { shotgun }\end{array}$ & Regulated CDSs \\
\hline \multirow[t]{9}{*}{1} & \multirow{7}{*}{226} & $\mathrm{D}$ & $\begin{array}{c}3032390 . . \\
3032595\end{array}$ & Yes & $\begin{array}{l}\text { PS E polysaccharide } \\
\text { biosynthesis region }\end{array}$ \\
\hline & & DD & $\begin{array}{c}894511 . . \\
894721\end{array}$ & No & $\begin{array}{l}\text { PS G polysaccharide } \\
\text { biosynthesis region. }\end{array}$ \\
\hline & & E & $\begin{array}{c}1634575 . . \\
1634805 \\
\end{array}$ & Yes & $\begin{array}{l}\text { PS A polysaccharide } \\
\text { biosynthesis region. }\end{array}$ \\
\hline & & $\mathrm{F}$ & $\begin{array}{c}4091660 . . \\
4091889\end{array}$ & Yes & $\begin{array}{l}\text { PS H polysaccharide } \\
\text { biosynthesis region. }\end{array}$ \\
\hline & & G & $\begin{array}{c}2211236 . . \\
2211454\end{array}$ & Yes & $\begin{array}{l}\text { PS B polysaccharide } \\
\text { biosynthesis region. }\end{array}$ \\
\hline & & $\mathrm{H}$ & $\begin{array}{c}4361354 . . \\
4361586\end{array}$ & Yes & $\begin{array}{l}\text { PS D polysaccharide } \\
\text { biosynthesis region. }\end{array}$ \\
\hline & & I & $\begin{array}{c}1806791 . . \\
1807023\end{array}$ & No & $\begin{array}{l}\text { PS F polysaccharide } \\
\text { biosynthesis region. }\end{array}$ \\
\hline & \multirow[t]{2}{*}{161} & A & $\begin{array}{c}89789 . . \\
89949\end{array}$ & No & $\begin{array}{l}\text { Putative membrane } \\
\text { protein. }\end{array}$ \\
\hline & & B & $\begin{array}{l}91906 . . \\
92066\end{array}$ & Yes & $\begin{array}{l}\text { Hypothetical protein. } \\
\text { Putative type I } \\
\text { restriction-modification } \\
\text { enzyme. }\end{array}$ \\
\hline
\end{tabular}




\begin{tabular}{|c|c|c|c|c|c|}
\hline & & C & $\begin{array}{c}129406 . . \\
129566\end{array}$ & Yes & $\begin{array}{l}\text { Hypothetical protein. } \\
\text { Membrane protein. } \\
\text { Putative SusC } \\
\text { homologue surface } \\
\text { membrane protein. }\end{array}$ \\
\hline & & $\mathrm{J}$ & $\begin{array}{c}4866094 . . \\
4866254\end{array}$ & Yes & $\begin{array}{l}\text { Conserved hypothetical } \\
\text { protein. } \\
\text { Hypothetical protein. }\end{array}$ \\
\hline & & K & $\begin{array}{c}4868436 . . \\
4868596\end{array}$ & No & $\begin{array}{l}\text { Hypothetical protein. } \\
\text { Putative membrane } \\
\text { protein. }\end{array}$ \\
\hline \multirow[t]{10}{*}{2} & \multirow[t]{10}{*}{370} & AA & $\begin{array}{l}603197 . . \\
603530 \\
\end{array}$ & Yes & $\begin{array}{l}\text { Putative exported } \\
\text { protein. }\end{array}$ \\
\hline & & L & $\begin{array}{c}5046156 . . \\
5046613\end{array}$ & Yes & $\begin{array}{l}\text { Putative exported } \\
\text { protein. } \\
\text { Putative } \\
\text { phosphoenolpyruvate } \\
\text { carboxykinase. }\end{array}$ \\
\hline & & M & $\begin{array}{c}3790067 . . \\
3790365\end{array}$ & Yes & $\begin{array}{l}\text { 10kDa chaperonin } \\
\text { GroES. } \\
\text { Putative exported } \\
\text { protein. }\end{array}$ \\
\hline & & $\mathrm{N}$ & $\begin{array}{c}5023725 . . \\
5024147\end{array}$ & Yes & $\begin{array}{l}\text { Putative outer } \\
\text { membrane protein. } \\
\text { Putative pyruvate } \\
\text { carboxylase biotin- } \\
\text { containing subunit. }\end{array}$ \\
\hline & & $\mathrm{O}$ & $\begin{array}{c}2282840 . . \\
2283132\end{array}$ & Yes & $\begin{array}{l}\text { Putative outer } \\
\text { membrane protein. }\end{array}$ \\
\hline & & $\mathrm{T}$ & $\begin{array}{c}2093020 . . \\
2094551\end{array}$ & Yes & $\begin{array}{l}\text { Putative gene cluster for } \\
\text { degradation of } \\
\text { sialoconjugates. }\end{array}$ \\
\hline & & V & $\begin{array}{c}4218300 . . \\
4218701\end{array}$ & No & $\begin{array}{l}\text { Putative exported } \\
\text { protein. } \\
\text { Conserved hypothetical } \\
\text { protein. } \\
\text { Putative anti-sigma } \\
\text { factor. }\end{array}$ \\
\hline & & W & $\begin{array}{c}3420744 . . \\
3421217\end{array}$ & No & $\begin{array}{l}\text { Putative anti-sigma } \\
\text { factor. } \\
\text { Putative ECF-sigma } \\
\text { factor, RpoE-like. }\end{array}$ \\
\hline & & $X$ & $\begin{array}{c}3754426 . . \\
3754869\end{array}$ & No & $\begin{array}{l}\text { Putative exported } \\
\text { protein. } \\
\text { Putative outer } \\
\text { membrane protein. }\end{array}$ \\
\hline & & $\mathrm{Y}$ & $\begin{array}{c}3839227 . . \\
3839616\end{array}$ & Yes & $\begin{array}{l}\text { Putative outer } \\
\text { membrane protein. } \\
\text { Putative outer } \\
\text { membrane receptor } \\
\text { protein. }\end{array}$ \\
\hline
\end{tabular}




\begin{tabular}{|l|l|l|c|c|l|}
\hline & Z & $\begin{array}{c}1121569 . . \\
1121954\end{array}$ & No & $\begin{array}{l}\text { Putative enoyl ACP- } \\
\text { reductase. }\end{array}$ \\
\hline
\end{tabular}

Table S2B - Other invertible regions.

\begin{tabular}{|c|c|c|c|c|}
\hline $\begin{array}{c}\text { Invertible } \\
\text { Region (IR) }\end{array}$ & Coordinates & $\begin{array}{c}\text { Active in } \\
\text { shotgun }\end{array}$ & CDSs involved & effect \\
\hline $\begin{array}{c}\text { BB } \\
\text { (multiple } \\
\text { inversions) }\end{array}$ & $\begin{array}{l}2147598 . . \\
2151089\end{array}$ & Yes & $\begin{array}{l}\text { Putative type I restriction- } \\
\text { modification endonuclease } \\
\text { specificity subunit. } \\
\text { BF1839, BF1840, BF1841, } \\
\text { BF1842 }\end{array}$ & $\begin{array}{l}\text { Exchange of DNA- } \\
\text { binding modules in } \\
\text { specificity subunit }\end{array}$ \\
\hline $\begin{array}{c}\text { CC } \\
\text { (multiple } \\
\text { inversions) }\end{array}$ & $\begin{array}{l}708692 . . \\
720999\end{array}$ & Yes & $\begin{array}{l}\text { Putative outer membrane } \\
\text { proteins. } \\
\text { BF0590, BF0592, BF0594, } \\
\text { BF0596 }\end{array}$ & $\begin{array}{l}\text { Switching of } \\
\text { alternative outer } \\
\text { membrane proteins } \\
\text { onto translational start } \\
\text { signals (fixed } \\
\text { promoter) } \\
\end{array}$ \\
\hline $\begin{array}{c}\text { EE } \\
\text { (multiple } \\
\text { inversions) }\end{array}$ & $\begin{array}{l}1999949 . . \\
2093942\end{array}$ & Partially & $\begin{array}{l}\text { Putative outer membrane } \\
\text { proteins. } \\
\text { BF1716, BF1719, BF1722, } \\
\text { BF1798, BF1803 }\end{array}$ & $\begin{array}{l}\text { Switching of } \\
\text { alternative outer } \\
\text { membrane proteins to } \\
\text { control by invertible } \\
\text { promoter in IR-T }\end{array}$ \\
\hline $\mathrm{P}$ & $\begin{array}{l}401492 . . \\
403339\end{array}$ & Yes & $\begin{array}{l}\text { Putative two-component } \\
\text { sensor histidine } \\
\text { kinase/response regulator } \\
\text { fusion. }\end{array}$ & $\begin{array}{l}\text { Fusion and separation } \\
\text { of sensor and } \\
\text { phospho-relay } \\
\text { components }\end{array}$ \\
\hline Q & $\begin{array}{l}2831962 . . \\
2833445\end{array}$ & Yes & $\begin{array}{l}\text { Hypothetical proteins. } \\
\text { BF2439A, BF2439B }\end{array}$ & $\begin{array}{l}\text { Alternative } \\
\text { orientation of two } \\
\text { hypothetical proteins } \\
\text { (with or against } \\
\text { direction of } \\
\text { transcription of } \\
\text { surrounding genes) } \\
\end{array}$ \\
\hline $\mathrm{R}$ & $\begin{array}{c}1073991 . . \\
1079515\end{array}$ & Yes & $\begin{array}{l}\text { Putative outer membrane } \\
\text { proteins. } \\
\text { BF0865, BF0866 }\end{array}$ & $\begin{array}{l}\text { Alternative } \\
\text { orientation of genes } \\
\text { (with or against } \\
\text { direction of } \\
\text { transcription of } \\
\text { surrounding genes }\end{array}$ \\
\hline S & $\begin{array}{l}1079501 . . \\
1087414\end{array}$ & Yes & $\begin{array}{l}\text { Putative outer membrane } \\
\text { proteins. BF0867, BF0868 } \\
\text { Putative RNA polymerase } \\
\text { ECF-sigma factor and } \\
\text { putative anti-sigma factor. } \\
\text { BF0869, BF0870 }\end{array}$ & $\begin{array}{l}\text { Alternative } \\
\text { orientation of genes }\end{array}$ \\
\hline
\end{tabular}


Table S3 - Polysaccharide biosynthesis operons.

\begin{tabular}{|l|c|c|c|c|c|}
\hline Region & Coordinates & $\begin{array}{c}\text { Variable } \\
\text { promoter } \\
\text { (IR) }\end{array}$ & $\begin{array}{c}\text { Active in } \\
\text { shotgun }\end{array}$ & Regulators & CDSs \\
\hline PS A & $1635470 . .1635940$ & E & Yes & UpaY / UpaZ & $\begin{array}{c}\text { BF1367 - } \\
\text { BF1377 }\end{array}$ \\
\hline PS B & $2211582 . .2234865$ & G & Yes & UpbY / UpbZ & $\begin{array}{c}\text { BF1893 - } \\
\text { BF1914 }\end{array}$ \\
\hline PS C & $1260915 . .1277396$ & $\begin{array}{c}\text { Non- } \\
\text { variable }\end{array}$ & - & UpcY / UpcZ & $\begin{array}{c}\text { BF1009 - } \\
\text { BF1026 }\end{array}$ \\
\hline PS D & $4346276 . .4361140$ & H & Yes & UpdY / UpdZ & $\begin{array}{c}\text { BF3683 - } \\
\text { BF3699 }\end{array}$ \\
\hline PS E & $3016482 . .3032253$ & D & Yes & UpeY / UpeZ & $\begin{array}{c}\text { BF2591 - } \\
\text { BF2606 }\end{array}$ \\
\hline PS F & $1807211 . .1822424$ & I & No & UpfY / UpfZ & $\begin{array}{c}\text { BF1549 - } \\
\text { BF1565 }\end{array}$ \\
\hline PS G & $894922 . .917651$ & DD & No & UpgY / UpgZ & $\begin{array}{c}\text { BF0731 - } \\
\text { BF0752 }\end{array}$ \\
\hline PS H & $4076795 . .4091435$ & F & Yes & UphY / UphZ & $\begin{array}{c}\text { BF3451 - } \\
\text { BF3466 }\end{array}$ \\
\hline PS I & $3249979 . .3278123$ & $\begin{array}{c}\text { Non- } \\
\text { variable }\end{array}$ & - & UpiY & $\begin{array}{c}\text { BF2790 - } \\
\text { BF2817 }\end{array}$ \\
\hline PS J & $1987522 . .2004910$ & $\begin{array}{c}\text { Non- } \\
\text { variable }\end{array}$ & - & & $\begin{array}{c}\text { BF1706 - } \\
\text { BF1718 }\end{array}$ \\
\hline
\end{tabular}

Table S4 - Putative SusC homologues.

\begin{tabular}{|c|c|c|c|}
\hline CDS & Coordinates & Product & $\begin{array}{c}\text { Invertible } \\
\text { region }\end{array}$ \\
\hline BF0229 & $250479 . .253874$ & $\begin{array}{l}\text { Putative SusC homologue outer membrane } \\
\text { protein }\end{array}$ & No \\
\hline BF0288 & $334274 . .337474$ & $\begin{array}{c}\text { Putative SusC homologue TonB-dependent } \\
\text { outer membrane protein }\end{array}$ & No \\
\hline BF0334 & $397798 . .401148$ & $\begin{array}{c}\text { Putative SusC homologue outer membrane } \\
\text { protein }\end{array}$ & No \\
\hline BF0341 & 412037..415084 & $\begin{array}{l}\text { Putative TonB-dependent outer membrane } \\
\text { exported protein }\end{array}$ & No \\
\hline BF0349 & $420462 . .423518$ & $\begin{array}{l}\text { Putative TonB dependent outer membrane } \\
\text { exported protein }\end{array}$ & No \\
\hline BF0381 & $465995 . .469327$ & Putative exported protein & No \\
\hline BF0501 & $581461 . .584628$ & Putative outer membrane protein & No \\
\hline BF0518 & $603565 . .606753$ & Putative outer membrane protein & No \\
\hline $\begin{array}{c}\text { frrG } \\
\text { (BF0536) }\end{array}$ & 629760..633170 & Putative outer membrane protein & No \\
\hline BF0571 & 680148..683426 & $\begin{array}{l}\text { Putative TonB-linked outer membrane } \\
\text { receptor protein }\end{array}$ & No \\
\hline BF0578 & 694072..696408 & $\begin{array}{l}\text { Putative TonB-dependent outer membrane } \\
\text { receptor protein }\end{array}$ & No \\
\hline
\end{tabular}




\begin{tabular}{|c|c|c|c|}
\hline BF0590 & 705773..708751 & $\begin{array}{l}\text { Putative SusC homologue surface } \\
\text { membrane protein }\end{array}$ & Yes \\
\hline BF0592 & 710759..713614 & $\begin{array}{l}\text { Putative SusC homologue surface } \\
\text { membrane protein }\end{array}$ & Yes \\
\hline BF0594 & 715846..718878 & $\begin{array}{c}\text { Putative SusC homologue surface } \\
\text { membrane protein }\end{array}$ & Yes \\
\hline BF0596 & $720940 . .723876$ & $\begin{array}{l}\text { Putative SusC homologue surface } \\
\text { membrane protein }\end{array}$ & Yes \\
\hline BF0661 & 797339..800476 & Putative outer membrane protein & No \\
\hline BF0681 & 828289..831702 & Putative outer membrane protein & No \\
\hline BF0711 & $871405 . .874152$ & $\begin{array}{l}\text { Putative TonB-dependent outer membrane } \\
\text { receptor protein }\end{array}$ & No \\
\hline BF0759 & $924125 . .927259$ & Putative outer membrane protein & No \\
\hline BF0807 & $989559 . .992741$ & Putative outer membrane protein & No \\
\hline BF0864 & 1070528..1073572 & conserved hypothetical protein & No \\
\hline BF0866 & 1075945..1079352 & Putative outer membrane protein & No \\
\hline BF0868 & 1081426..1084734 & $\begin{array}{l}\text { Putative TonB-linked outer membrane } \\
\text { protein }\end{array}$ & No \\
\hline BF0871 & 1087602..1090943 & Putative exported protein & No \\
\hline BF0890 & 1111869..1115135 & Putative outer membrane receptor protein & No \\
\hline BF0893 & 1118124..1121387 & Putative outer membrane receptor protein & No \\
\hline BF0971 & 1213148..1216468 & Putative outer membrane protein & No \\
\hline BF0977 & 1222361..1225738 & $\begin{array}{l}\text { Putative TonB-dependent outer membrane } \\
\text { receptor protein }\end{array}$ & No \\
\hline BF1204 & 1463991..1467359 & Putative outer membrane protein & No \\
\hline BF1310 & 1570137..1573439 & Putative outer membrane protein & No \\
\hline BF1415 & 1679751..1683143 & Putative outer membrane protein & No \\
\hline BF1512 & $1771475 . .1774855$ & Putative outer membrane protein & No \\
\hline BF1618 & 1886174..1889299 & Putative outer membrane receptor protein & No \\
\hline BF1716 & $1999994 . .2002084$ & $\begin{array}{c}\text { Putative SusC homologue outer membrane } \\
\text { protein }\end{array}$ & Yes \\
\hline BF1719 & $2005661 . .2008927$ & $\begin{array}{l}\text { Putative SusC homologue outer membrane } \\
\text { protein }\end{array}$ & Yes \\
\hline BF1722 & $2012226 . .2015546$ & $\begin{array}{l}\text { Putative SusC homologue outer membrane } \\
\text { protein }\end{array}$ & Yes \\
\hline BF1798 & 2081856..2085086 & $\begin{array}{l}\text { Putative SusC homologue outer membrane } \\
\text { protein }\end{array}$ & Yes \\
\hline BF1803 & 2090601..2093867 & $\begin{array}{l}\text { Putative SusC homologue outer membrane } \\
\text { protein }\end{array}$ & Yes \\
\hline BF1804 & $2094629 . .2097796$ & $\begin{array}{l}\text { Putative TonB-dependent outer membrane } \\
\text { receptor protein }\end{array}$ & No \\
\hline BF1816 & $2119766 . .2122507$ & Putative outer membrane protein & No \\
\hline
\end{tabular}




\begin{tabular}{|c|c|c|c|}
\hline BF1956 & $2283190 . .2286564$ & Putative outer membrane protein & No \\
\hline BF1992 & 2330851..2334225 & Putative outer membrane protein & No \\
\hline BF2044 & 2387138..2389924 & $\begin{array}{l}\text { Putative TonB-dependent outer membrane } \\
\text { receptor protein }\end{array}$ & No \\
\hline BF2084 & 2437288..2439492 & $\begin{array}{l}\text { Putative TonB-dependent outer membrane } \\
\text { receptor protein }\end{array}$ & No \\
\hline BF2195 & $2557432 . .2560734$ & Putative exported protein & No \\
\hline BF2270 & $2654934 . .2658200$ & Putative exported protein & No \\
\hline BF2697 & 3136811..3139111 & $\begin{array}{l}\text { Putative exported TonB-dependent receptor } \\
\text { protein }\end{array}$ & No \\
\hline BF2708 & 3149210..3151351 & $\begin{array}{l}\text { Putative exported TonB-dependent receptor } \\
\text { protein }\end{array}$ & No \\
\hline BF2907 & $3376170 . .3379502$ & Putative exported protein & No \\
\hline BF2942 & 3416623..3419997 & Putative exported protein & No \\
\hline BF3024 & 3515789..3518941 & Putative exported protein & No \\
\hline BF3097 & $3612821 . .3616255$ & Putative exported protein & No \\
\hline BF3146 & $3670784 . .3673789$ & Putative exported protein & No \\
\hline BF3199 & 3754969..3758121 & Putative exported protein & No \\
\hline BF3258 & 3835857..3839033 & Putative exported protein & No \\
\hline BF3307 & $3899923 . .3903075$ & Putative exported protein & No \\
\hline $\begin{array}{c}\text { omp117 } \\
\text { (BF3412) }\end{array}$ & $4024110 . .4027376$ & Putative outer membrane protein & No \\
\hline BF3444 & $4066003 . .4069050$ & Putative membrane protein & No \\
\hline BF3572 & $4206914 . .4210357$ & Putative membrane protein & No \\
\hline BF3576 & $4214892 . .4218104$ & Putative exported protein & No \\
\hline BF3581 & $4222187 . .4225660$ & Putative membrane protein & No \\
\hline BF3642 & $4297965 . .4300640$ & Putative exported protein & No \\
\hline BF3712 & $4374951 . .4378244$ & Putative exported protein & No \\
\hline BF3724 & 4392109..4395414 & Putative exported protein & No \\
\hline BF3746 & 4419207..4422644 & Putative membrane protein & No \\
\hline BF4056 & $4769105 . .4772347$ & Putative outer membrane protein & No \\
\hline BF4062 & 4781654..4784647 & $\begin{array}{c}\text { Putative TonB-linked outer membrane } \\
\text { protein }\end{array}$ & No \\
\hline BF4132 & $4860945 . .4864271$ & Putative outer membrane protein & No \\
\hline BF4169 & $4911410 . .4914403$ & $\begin{array}{c}\text { Putative TonB-linked outer membrane } \\
\text { protein }\end{array}$ & No \\
\hline BF4178 & $4932416 . .4935583$ & Putative outer membrane protein & No \\
\hline BF4246 & $5030783 . .5033878$ & Putative outer membrane protein & No \\
\hline
\end{tabular}




\begin{tabular}{|c|c|c|c|}
\hline BF4248 & $5030783 . .5033878$ & Putative outer membrane protein & No \\
\hline BF4256 & $5046824 . .5050081$ & Putative outer membrane protein & No \\
\hline BF4268 & $5067453 . .5070962$ & $\begin{array}{c}\text { Putative outer membrane protein } \\
\text { (pseudogene) }\end{array}$ & No \\
\hline BF4323 & $5135539 . .5138736$ & $\begin{array}{c}\text { Putative TonB-dependent outer membrane } \\
\text { receptor protein }\end{array}$ & No \\
\hline
\end{tabular}

\section{Supporting References}

1. $\quad$ R. L. Van Tassell, T. D. Wilkins, Can J Microbiol 24, 1619-21 (1978).

2. S. Patrick, M. J. Larkin, in Microbial biofilms: Formation and Control S. P. Denyer, Ed. (Blackwell Scientific Publications, Oxford, 1993) pp. 109-131.

3. F. M. Ausubel et al., Short Protocols in Molecular Biology 2nd Edition. J. Wiley, Ed. (Chichester, 1992).

4. J. Parkhill et al., Nature 404, 502-6 (2000).

5. $\quad$ K. Rutherford et al., Bioinformatics 16, $944-5$ (2000).

6. J. Xu et al., Science 299, 2074-6 (2003).

7. J. Parkhill et al., Nature 413, 848-52 (2001).

8. J. Parkhill et al., Nature 413, 523-7 (2001).

9. S. A. Hanley, J. Aduse-Opoku, M. A. Curtis, Infect Immun 67, 1157-71 (1999).

10. K. H. Cho, A. A. Salyers, J Bacteriol 183, 7224-30 (2001).

11. T. Komano, Annual Review of Genetics 33, 171-191 (1999).

12. G. S. Moeck, J. W. Coulton, Mol Microbiol 28, 675-81 (1998).

13. B. R. Otto, J. G. Kusters, J. Luirink, F. K. de Graaf, B. Oudega, Infect Immun 64, 4345-50 (1996).

14. V. H. Varel, M. P. Bryant, Appl Microbiol 28, 251-7 (1974).

15. S. Patrick, in Molecular Medical Microbiology M. Sussman, Ed. (Academic Press, London, 2002) pp. 1921-1948.

16. H. Tanaka, F. Ito, T. Iwasaki, J Biochem (Tokyo) 115, 318-21 (1994).

17. J. R. Baker, S. Dong, D. G. Pritchard, Biochem J 365, 317-22 (2002).

18. M. J. Pallen, A. C. Lam, N. Loman, Trends Microbiol 9, 518-21 (2001).

19. S. Patrick, Coffey, A., Emmerson, A.M., and Larkin, M.J., FEMS Microbiology Letters 50, 67-71 (1988).

20. S. Patrick, B. I. Duerden, in Principles and Practice of Clinical Bacteriology S. H. G. Hawkey, Ed. (J. Wiley, London, 2004).

21. R. C. Wang et al., J Mol Biol 217, 441-54 (1991).

22. S. Patrick, J. P. McKenna, S. O'Hagan, E. Dermott, Microb Pathog 20, 191-202 (1996).

23. A. J. Cooper, A. P. Kalinowski, N. B. Shoemaker, A. A. Salyers, J Bacteriol 179, 6221-7 (1997).

24. H. J. Goodman, D. R. Woods, Gene 94, 77-82 (1990).

25. G. A. Cromie, J. C. Connelly, D. R. Leach, Mol Cell 8, 1163-74 (2001).

26. M. A. Petit, and Erlich, D., EMBO Jounal 21, 3137-3147 (2002).

27. A. Quiberoni et al., Res Microbiol 152, 131-9 (2001).

28. M. S. Dillingham, M. Spies, S. C. Kowalczykowski, Nature 423, 893-7 (2003). 